This is an electronic reprint of the original article. This reprint may differ from the original in pagination and typographic detail.

Author(s): Vesterinen, Jussi; Devlin, Shawn; Syväranta, Jari; Jones, Roger

Title: Influence of littoral periphyton on whole-lake metabolism relates to littoral vegetation in humic lakes

Year: $\quad 2017$

Version:

Please cite the original version:

Vesterinen, J., Devlin, S., Syväranta, J., \& Jones, R. (2017). Influence of littoral periphyton on whole-lake metabolism relates to littoral vegetation in humic lakes. Ecology, 98(12), 3074-3085. https://doi.org/10.1002/ecy.2012

All material supplied via JYX is protected by copyright and other intellectual property rights, and duplication or sale of all or part of any of the repository collections is not permitted, except that material may be duplicated by you for your research use or educational purposes in electronic or print form. You must obtain permission for any other use. Electronic or print copies may not be offered, whether for sale or otherwise to anyone who is not an authorised user. 


\title{
Influence of littoral periphyton on whole-lake metabolism relates to littoral vegetation in humic lakes
}

\author{
Jussi Vesterinen, ${ }^{1,4}$ Shawn P. Devlin, ${ }^{1,2}$ Jari Syväranta, ${ }^{1,3}$ And Roger I. Jones ${ }^{1}$ \\ ${ }^{1}$ Department of Biological and Environmental Science, University of Jyväskylä, P.O. Box 35, Jyväskylä FI-40014 Finland \\ ${ }^{2}$ Flathead Lake Biological Station, University of Montana, Polson, Montana 59860 USA \\ ${ }^{3}$ Department of Environmental and Biological Sciences, University of Eastern Finland, P.O. Box 111, Joensuu 80101 Finland
}

\begin{abstract}
The role of littoral habitats in lake metabolism has been underrated, especially in humic lakes, based on an assumption of low benthic primary production (PP) due to low light penetration into water. This assumption has been challenged by recent recognition of littoral epiphyton dominance of whole-lake PP in a small highly humic lake and of epiphyton as an important basal food source for humic lake biota. However, as these studies have mostly concerned single lakes, there is a need to test their wider generality. We studied the whole-lake PP and community respiration (CR) in eight small humic lakes in southern Finland during July 2015 using ${ }^{14} \mathrm{C}$ incorporation to measure pelagic $\mathrm{PP}$ and the changes in dissolved inorganic carbon in light and dark in situ incubations to measure CR and littoral PP by epiphyton. Changes in $\mathrm{O}_{2}$ concentration in both pelagic and littoral surface water were measured periodically from each lake and, additionally, continuously with a data logger from one lake during the study period. The results revealed that the littoral dominated whole-lake net primary production (NPP) in five of the eight lakes, which was supported by observed $\mathrm{O}_{2}$ supersaturation in the littoral surface water in most of the lakes. Calculated pelagic:littoral ratios by area correlated negatively with both littoral NPP and littoral contribution to whole-lake NPP. Moreover, there was a significant positive relationship between littoral proportion of whole-lake NPP and the fraction of lake surface area covered by littoral aquatic vegetation. This demonstrates that increased aquatic littoral vegetation cover increases the overall importance of the littoral to whole-lake PP in highly humic lakes. Littoral NPP also correlated strongly with littoral $\mathrm{O}_{2}$ saturation, and the continuously measured $\mathrm{O}_{2}$ revealed substantial temporal variation in $\mathrm{O}_{2}$ saturation, particularly in the littoral zone. Whole-lake gross primary production:community respiration (GPP:CR) ratios revealed that accounting for littoral metabolism produced a marked shift towards lake metabolic balance, although all the eight lakes remained net heterotrophic. This study emphasizes that littoral metabolism needs to be accounted for when estimating whole-lake $\mathrm{C}$ fluxes in all lakes, even in highly colored humic waters.
\end{abstract}

Key words: boreal lakes; community respiration; epiphyton; lake browning; lake metabolism; whole-lake primary production.

\section{INTRODUCTION}

Most studies of production in lakes have concerned only the pelagic habitat without measuring littoral autotrophic production and metabolism (Vadeboncoeur et al. 2002, Cantonati and Lowe 2014). Of the few studies covering both habitats most have focused either on eutrophic or clear oligotrophic lakes (Vadeboncoeur et al. 2003, Andersson and Brunberg 2006, Ask et al. 2009a, Devlin et al. 2015), where littoral autotrophy can make a substantial contribution to whole-lake primary production (PP). If lakes are steep-sided, general models of benthic algal production, based on variables such as light, basin morphometry and nutrients, yield a negligible benthic contribution to whole-lake PP (Vadeboncoeur et al. 2008). However, these models do not account for the surrounding aquatic

Manuscript received 24 January 2017; revised 14 July 2017; accepted 1 September 2017. Corresponding Editor: Elisabeth S. Bakker.

${ }^{4}$ E-mail: jussi.p.vesterinen@jyu.fi and submerged terrestrial vegetation which varies greatly between lakes and is important for many interactions in lake communities (Jeppesen et al. 2012).

In highly humic lakes the role of the littoral zone in whole-lake PP has been particularly underrated based on an assumption of low benthic PP due to the very low light penetration into water. Many boreal lakes have high concentrations of allochthonous dissolved organic matter (DOM) rich in humic substances, which restrict light penetration to the uppermost water layers and absorb heat very efficiently, resulting in steep vertical temperature and $\mathrm{O}_{2}$ gradients. While allochthonous DOM directly controls light and temperature conditions, it also affects PP, metabolic rates and several other fundamental functions in lake ecosystems (Solomon et al. 2015). Besides constraining intrinsic PP (Karlsson et al. 2009), incorporation of allochthonous organic carbon into lake food webs increases community respiration (CR), which is often reported to exceed gross primary production (GPP) and make lakes net heterotrophic (Del Giorgio and Peters 1994, Duarte and Agusti 1998). Small boreal lakes are 
predominately shallow due to flat topography, and allochthonous inputs are diluted in a small volume of water, resulting in higher water color than in deeper lakes (Kortelainen 1999). Many surface waters of glaciated landscapes across North America and Europe have experienced an increase in dissolved organic carbon (DOC) concentration, which is expected to continue in the future (e.g. Monteith et al. 2007, Solomon et al. 2015). As this lake "browning" further limits light availability in lakes, it presumably has a negative effect on benthic PP (Brothers et al. 2014).

However, small humic boreal lakes often have surrounding floating moss stands among other emergent, floating and submerged aquatic macrophytes, and this surrounding vegetation has been reported to have expanded over recent decades in Finnish lakes (Rintanen 1996). These vegetation stands can provide extensive substrata for epiphyton growth in relatively well-illuminated conditions just under the water surface. Particularly lakes surrounded by floating moss stands tend to have treeless shores and, thus, negligible shading. Vesterinen et al. (2016) recently reported that PP of epiphyton on the littoral vegetation dominated the summer whole-lake PP in a small humic lake. Concurrent measurements of $\mathrm{CR}$ revealed that the littoral was strongly net autotrophic, to the extent of being able to balance the whole-lake metabolism and even make the lake net autotrophic occasionally during the open water period. As lakes of similar size are very common throughout the boreal zone, while globally the estimated total number of lakes with surface area from 0.1 to 1 ha is $2.77 \times 10^{8}$ (Downing et al. 2006, Messager et al. 2016), these findings can be expected to have wider applicability.

Hence the prevailing view of a very low contributions of littoral production to whole-lake PP in humic lakes is being challenged by recent studies. However, as the evidence derives largely from studies of individual lakes there is a clear need to test the wider generality of the findings. In this study we investigated the prevalence of highly productive littoral habitats in several small humic lakes in southern Finland. We studied the magnitudes of autotrophic production and respiration in both the pelagic and littoral habitats of the lakes during July 2015, extrapolated results to the whole-lake scale and related the values to different environmental variables. We predicted that the littoral epiphyton would make a substantial contribution to whole-lake PP and strongly influence the apparent whole-lake metabolic balance, and that the littoral epiphytic contribution to whole-lake PP would be related to the extent of available substrata in lakes.

\section{Methods \\ Study lakes}

The study was conducted between 8 and 22 July 2015 and encompassed eight lakes located in the Evo forest area in southern Finland (an area of ca. $18 \mathrm{~km}^{2}$ between $61^{\circ} 10^{\prime}$ and $61^{\circ} 13^{\prime} \mathrm{N}$ and $25^{\circ} 5^{\prime}$ and $25^{\circ} 12^{\prime} \mathrm{E}$;
Appendix S1: Fig. S1). This area contains mainly small humic headwater lakes inter-connected by brooks and forming a network of lakes in the landscape (Järvinen et al. 2002, Vehkaoja et al. 2015). Most of these lakes have one or more inflows and one outflow and are predominantly fed by surface runoff, while a smaller fraction of the lakes are seepage lakes (Arvola et al. 2010).

The study lakes are small (mean \pm SE surface area $1.0 \pm 0.2$ ha) and highly humic (mean \pm SE water color $280 \pm 57 \mathrm{mg} \mathrm{Pt} \mathrm{L}^{-1}$ ). The lakes are surrounded by coniferous forest with patches of deciduous trees. Except for Lakes Horkkajärvi, Tavilammi and Keskinen Rajajärvi, trees do not grow directly along the shores of the lakes, making littoral areas well-lit. Some shading by trees does occur at those three lakes in places where trees extend closer to the shoreline. There is no agricultural activity remaining in the study area, and the development of the forests in Evo is strongly influenced by commercial forestry. The lakes have ice cover usually from early November until the beginning of May. Being highly colored, light penetration is restricted to the uppermost water layers, and steep temperature and $\mathrm{O}_{2}$ gradients form very rapidly in the water column after ice-off in spring, with anoxia developing in the hypolimnion in every study lake. Most of these lakes are steep-sided and have very little illuminated benthic area, but some do have some shallower areas close to the lake edges, where light can penetrate to the bottom. Littoral areas consist mostly of aquatic vegetation (macrophytes and bryophytes) and associated epiphytes, which both vary among the lakes. A peripheral floating moss mat (mostly of Warnstorfia and Sphagnum species) is a predominant characteristic in Lakes Mekkojärvi, Möläkkä and Nimetön. Littoral areas in these lakes also comprise sedges (Carex sp.), which grow on the lake bank and are partly fallen into the lake and often in various stages of decay, along with some other floating, emergent and submerged macrophytes, such as Menyanthes trifoliata, Phragmites australis and Utricularia sp. Lakes Horkkajärvi and Tavilammi have the most bare rocky shore and the least aquatic vegetation with some patchy appearance of emergent and floating macrophytes. Lakes Haukijärvi, Huhmari and Keskinen Rajajärvi can be considered as intermediate in terms of vegetation cover, which consists mostly of some floating, emergent and submerged plants, but without such an extensive moss bed as in Mekkojärvi and Nimetön. All the study lakes, except for Keskinen Rajajärvi, have been monitored ca. twice per year (in spring and in autumn) by staff from nearby Lammi Biological Station so that some additional chemical and physical parameters not measured in this study were available. More characteristics of the study lakes are presented in Table 1 and Appendix S2: Table S1.

\section{Physical parameters}

Light attenuation was measured at $0.5 \mathrm{~m}$ intervals from the surface to the bottom in the pelagic area of 
TABLE 1. Some characteristics of the eight study lakes. All the presented chemical parameters except chl $a$ were provided by Lammi Biological Station. SA $=$ Surface area, $\mathrm{CA}=$ Catchment area, P:L ratio $=$ Pelagic:Littoral ratio by area, ${ }^{*}=$ Sampled on 3.11.2015, $* *$ = Sampled on 27.-28.11.2014, $* * *=$ sampled from epilimnion.

\begin{tabular}{|c|c|c|c|c|c|c|c|c|c|c|c|c|}
\hline Lake & $\begin{array}{c}\text { Sampling } \\
\text { date }\end{array}$ & $\begin{array}{l}\text { SA } \\
\text { (ha) }\end{array}$ & $\begin{array}{l}\text { CA } \\
\text { (ha) }\end{array}$ & $\begin{array}{l}\text { Max. } \\
\text { depth } \\
(\mathrm{m})\end{array}$ & $\begin{array}{l}\text { Mean } \\
\text { depth } \\
(\mathrm{m})\end{array}$ & $\begin{array}{l}\mathrm{P}: \mathrm{L} \\
\text { ratio }\end{array}$ & $\mathrm{pH}^{*}$ & $\begin{array}{c}\text { Color } \\
\left(\mathrm{mg} \mathrm{Pt} \mathrm{L}^{-1}\right)^{*}\end{array}$ & $\begin{array}{c}\text { Tot-N } \\
\left(\mu \mathrm{g} \mathrm{L}^{-1}\right)^{*}\end{array}$ & $\begin{array}{c}\text { Tot-P } \\
\left(\mu \mathrm{g} \mathrm{L}^{-1}\right)^{*}\end{array}$ & $\begin{array}{c}\mathrm{DOC} \\
\left(\mathrm{mg} \mathrm{L}^{-1}\right)^{* *}\end{array}$ & $\begin{array}{c}\mathrm{Chl} a \\
\left(\mathrm{mg} \mathrm{m}^{-3}\right)^{* * *}\end{array}$ \\
\hline Mekkojärvi & 8.7 .2015 & 0.4 & 24.8 & 4.3 & 2.0 & 3.0 & 5.9 & 429.0 & 635.0 & 16.0 & 24.0 & 3.0 \\
\hline Horkkajärvi & 9.7 .2015 & 1.1 & 62.1 & 12 & 7.7 & 19.8 & 5.9 & 402.0 & 745.0 & 21.0 & 27.0 & 4.9 \\
\hline Huhmari & 13.7 .2015 & 1.1 & 102.0 & 8 & 4.2 & 5.5 & 6.4 & 34.0 & 265.0 & 8.0 & 6.0 & 6.6 \\
\hline Möläkkä & 14.7 .2015 & 0.7 & 4.4 & 15 & 6.0 & 5.4 & 4.6 & 233.0 & 593.0 & 23.0 & 16.0 & 5.4 \\
\hline Nimetön & 15.7.2015 & 0.4 & 32.3 & 11 & 8.6 & 2.9 & 4.6 & 449.0 & 758.0 & 18.0 & 30.0 & 1.5 \\
\hline Tavilammi & 16.7 .2015 & 0.8 & 18.1 & 7 & 5.2 & 8.9 & 4.6 & 199.0 & 680.0 & 15.0 & 14.0 & 10.7 \\
\hline $\begin{array}{l}\text { Keskinen } \\
\text { Rajajärvi }\end{array}$ & 21.7 .2015 & 1.5 & 109.9 & 12 & 6.6 & 4.0 & $\mathrm{n} / \mathrm{a}$ & $\mathrm{n} / \mathrm{a}$ & $\mathrm{n} / \mathrm{a}$ & $\mathrm{n} / \mathrm{a}$ & $\mathrm{n} / \mathrm{a}$ & 15.1 \\
\hline Haukijärvi & 22.7 .2015 & 2.3 & 661.3 & 8.5 & 3.8 & 8.4 & 6.5 & 216.0 & 524.0 & 13.0 & 22.0 & 7.1 \\
\hline
\end{tabular}

every study lake using a single planar LI-COR (Li-192) Underwater Quantum light sensor (LI-COR Inc., Lincoln, Nebraska, USA). Temperature and $\mathrm{O}_{2}$ concentrations were measured at $0.5 \mathrm{~m}$ intervals from the pelagic areas and at six randomly selected sites from the littoral areas with a YSI $55 \mathrm{O}_{2}$ and temperature sensor (YSI Inc., Yellow Springs, Ohio, USA). In Mekkojärvi, two miniDO $\mathrm{O}_{2} \mathrm{~T}$ data loggers (PME Inc., Vista, California, USA) were used to record littoral and pelagic surface temperatures and $\mathrm{O}_{2}$ concentrations continuously during July. One data logger was placed above the moss mat (but under the water surface) in the littoral and the other was in the pelagic ca. $1 \mathrm{~m}$ from the edge of the littoral vegetation. Daily irradiance values (measured with a Kipp \& Zonen B.V., model CM11; Delft, The Netherlands) and day lengths were obtained from the Finnish Meteorological Institute measurement station in Jokioinen, ca. $110 \mathrm{~km}$ west from our study area in Evo. The area of littoral vegetation mat in each study lake was calculated from a satellite image using an area calculator tool (in Retkikartta.fi, (c) Metsähallitus, MML, CGI, 2016) and this was used for estimating pelagic:littoral ratios ( $\mathrm{P}: \mathrm{L}$ ratios) by area for each lake.

\section{Pelagic chlorophyll a, phytoplankton primary production and community respiration}

Chlorophyll $a(\operatorname{chl} a)$ was measured from $0.2-0.5 \mathrm{~m}$ depth (representing the epilimnion) from each lake. Samples were filtered onto Whatman GF/C glass fiber filters and chl $a$ was measured using a Shimadzu UV1800 spectrophotometer (Shimadzu Corporation, Kyoto, Japan) according to a standard spectrophotometric method SFS 5772 (Finnish Standards Association, Helsinki, Finland).

Pelagic PP was measured according to the ${ }^{14} \mathrm{C}$ incorporation method described by Schindler et al. (1972). Composite water samples were taken with an acrylic tube sampler Limnos (Limnos Ltd., Komorów, Poland) by combining three pulls from each of four strata corresponding to surface, epi-, meta- and hypolimnion in each lake, which were determined according to $\mathrm{O}_{2}$ measurements. Subsamples were decanted into $20 \mathrm{~mL}$ glass vials containing $\mathrm{NaH}^{14} \mathrm{CO}_{3}$ with four replicates (one dark sample in each depth) and were then incubated in situ in each stratum for $24 \mathrm{~h}$. The ${ }^{14} \mathrm{C}$ activity was measured with a Packard Tri-Carb ${ }^{\circledR}$ liquid scintillation counter (PerkinElmer, Waltham, Massachusetts, USA). $24 \mathrm{~h}$ incubations were expected to yield PP values which approximate most closely to net primary production (NPP) (Salonen and Holopainen 1979, Marra 2009). PP of the water column was converted from volumetric basis to areal basis by multiplying the values from each stratum by the total depth of the stratum and then summing over the whole water column. Whole-lake daily PP was estimated by multiplying the daily areal values by the lake surface area.

Pelagic CR was measured concurrently with PP as the increase of dissolved inorganic carbon (DIC) concentration during dark incubations. Subsamples (two initials and two samples for dark incubations) were taken from the composite water samples from each stratum (surface, epi-, meta- and hypolimnion) into $50 \mathrm{~mL}$ glass BOD bottles. Half of the bottles were wrapped in aluminium foil, put into light-impermeable tubes (filled with water) and incubated in situ in each stratum for $24 \mathrm{~h}$. The other half $\left(t_{0} \mathrm{~h}\right)$ were placed on ice and taken immediately to the laboratory, where DIC was measured with a DICanalyzer (Salonen 1981), and this was repeated for $t_{24} \mathrm{~h}$ samples the next day. From each bottle, five replicate subsamples were used to determine the median DIC concentrations of each sample. DIC samples were not acidified in the field, since the time gap between the samplings and measurements were only ca. $30 \mathrm{~min}$. The areal values for $\mathrm{CR}$ were calculated by multiplying the average volumetric values by the mean depth, and the whole-lake estimates were calculated as for PP.

\section{Littoral primary production, community respiration and periphyton biomass}

Periphyton PP and CR in littoral habitats were measured concurrently with the pelagic measurements from the difference of DIC during in situ incubations of 
epiphyton samples in both dark and transparent $20 \mathrm{~mL}$ glass vials, where consumption or production of DIC over time indicates either production or respiration. Following the methods described by Vesterinen et al. (2016), we mostly sampled sedges and other plant substrata which had died, as these were effectively metabolically inert and easier to process compared to the more complex moss substratum. Validation of this method is based on comparison of PP on moss and sedges (conducted in 2011 in Lake Mekkojärvi, Vesterinen unpublished data), which showed no statistically significant difference. The samples were collected from six randomly selected sites around the lake shoreline by clipping randomly chosen pieces of plant substratum (four replicates per site) into $20 \mathrm{~mL}$ glass vials and filling with surrounding littoral water. The depth from which the samples originated ranged usually from 0.05 to $0.25 \mathrm{~m}$. Trial incubations of bare littoral water had not revealed substantive changes in DIC concentrations over time (Vesterinen et al. 2016). Surrounding littoral water was sampled from each site to obtain initial DIC concentrations. Periphyton samples were incubated in situ for $2 \mathrm{~h}$ around noon, half of the samples in the dark conditions and the other half in the surface water under the same light condition as those from which the periphyton originated (barely submerged under the water surface). After the incubations, the samples were placed on ice in a cool box and taken to the laboratory where DIC concentrations were measured immediately with a DIC-analyzer (Salonen 1981). Periphyton was then entirely removed from the substrata of six randomly selected samples by scraping with a spatula and the samples were filtered onto glass fiber filters (Whatman GF-F). Chl $a$ contents in these were measured as described above for phytoplankton, and the periphyton biomass was estimated as the total chl $a$ per dry weight (DW) of substratum in a sample. Substrata were dried at $60^{\circ} \mathrm{C}$ for $24 \mathrm{~h}$ and dry mass was recorded.

Gross primary production (GPP) of periphyton was calculated from the difference in DIC between light and dark samples $\left(\mathrm{GPP}=\mathrm{DIC}_{\mathrm{dark}}-\mathrm{DIC}_{\text {light }} /\right.$ incubation time $)$ and the CR from the differences between dark and initial samples $\left(\mathrm{DIC}_{\mathrm{dark}}-\mathrm{DIC}_{\text {initial }} /\right.$ incubation time $)$. NPP was then calculated as NPP $=\mathrm{GPP}-\mathrm{CR}$, assuming that most of the CR is attributable to primary producers (Vesterinen et al. 2017). The values of each sample were normalized to $\mathrm{mg} \mathrm{C} \mathrm{g} \mathrm{DW} \mathrm{substratum}{ }^{-1}$. To estimate the wholelake littoral PP, the availability of littoral substrata at each lake was quantified according to Vesterinen et al. (2016). The littoral substratum along $50 \mathrm{~cm}$ of lakeshore from six sites around the lake was entirely removed, carefully collected and dried at $60^{\circ} \mathrm{C}$ for $48 \mathrm{~h}$. Light penetration into each lake was used to determine the depth to which submerged and emergent macrophytes were removed (the depth reached by $1 \%$ of incident photosynthetically active radiation). Only the illuminated top layer was removed from those lakes in which the littoral consisted of dense vegetation beds. The average DW of littoral substratum per meter of lake shore was calculated for each lake and, as the substratum consists mainly of flat and horizontally aggregated macrophytes and moss leaves, the weight was divided by two in order to estimate the mass of the illuminated side of the substratum. This method was evaluated by Vesterinen et al. (2016) for Lake Mekkojärvi and concluded to be conservative. Daily PP was calculated according to Vesterinen et al. (2016) using Eq. 1, which is a modified version of the calculation described by Vadeboncoeur et al. (2008). For whole-lake estimates, PP per meter of lake shore was calculated and multiplied by the total shoreline length of each lake. Daily estimates for periphyton respiration were calculated by multiplying the mean hourly values around noon by 24 .

$$
\text { Periphyton } \mathrm{PP}^{- \text {day }}=\Delta t \sum_{\text {sunrise }}^{\text {sunset }}\left[\mathrm{PP}_{\max } \tan h\left(I_{z t} / I_{k}\right)\right]
$$

where $\Delta t$ is the time increment $(h), \mathrm{PP}_{\max }$ is the lightsaturated primary production right under the water surface at noon (mg C g dry-weighted substratum ${ }^{-1} \mathrm{~h}^{-1}$ ), $\tan h$ is the hyperbolic tangent function, $I_{z t}$ is the light at depth $z\left(\mu \mathrm{mol} \mathrm{m}{ }^{-2} \mathrm{~s}^{-1}\right)$ and time $t(h)$ and $I_{k}$ is the light intensity for onset of saturation, which was set to $300 \mu \mathrm{mol} \mathrm{m}{ }^{-2} \mathrm{~s}^{-1}$ according to Hill (1996). The irradiance data and day lengths were obtained from the Finnish Meteorological Institute in Jokioinen. To define $I_{z}$, the photosynthetically active radiation (PAR) on the surface was multiplied by the fraction of PAR at the incubation depth in each lake.

\section{Statistical analyses}

Welch's $t$-test was used to test for differences in pelagic and littoral NPP and CR and periphyton chl $a$ between the lakes, when sample sizes were unequal. Logtransformation was used for data with unequal variances, and the Tukey post-hoc test was used to explore which means were significantly different from each other. Regression analysis was used to test the relationships between epilimnetic NPP and chl $a$, periphyton NPP and periphyton chl $a$, littoral NPP and P:L ratio, littoral proportion of whole-lake NPP and P:L ratio, and littoral $\mathrm{O}_{2}$ saturation and littoral NPP. All the statistical tests were conducted with IBM SPSS Statistics (version 20.0.0.2; IBM, Armonk, New York, USA). The daily estimates of periphyton PP (Eq. 1) were performed using R project for Statistical Computing version 3.3.2 (R Core Team, 2016). All the descriptive statistics are reported as means \pm SE if not expressly noted.

\section{RESULTS}

\section{Physical parameters in pelagic and littoral areas}

Light attenuation was rapid in all the lakes (Fig. 1A), with the depth of $1 \%$ of surface irradiance being between 0.5 and $1.0 \mathrm{~m}$. Surface water temperatures in the pelagic 

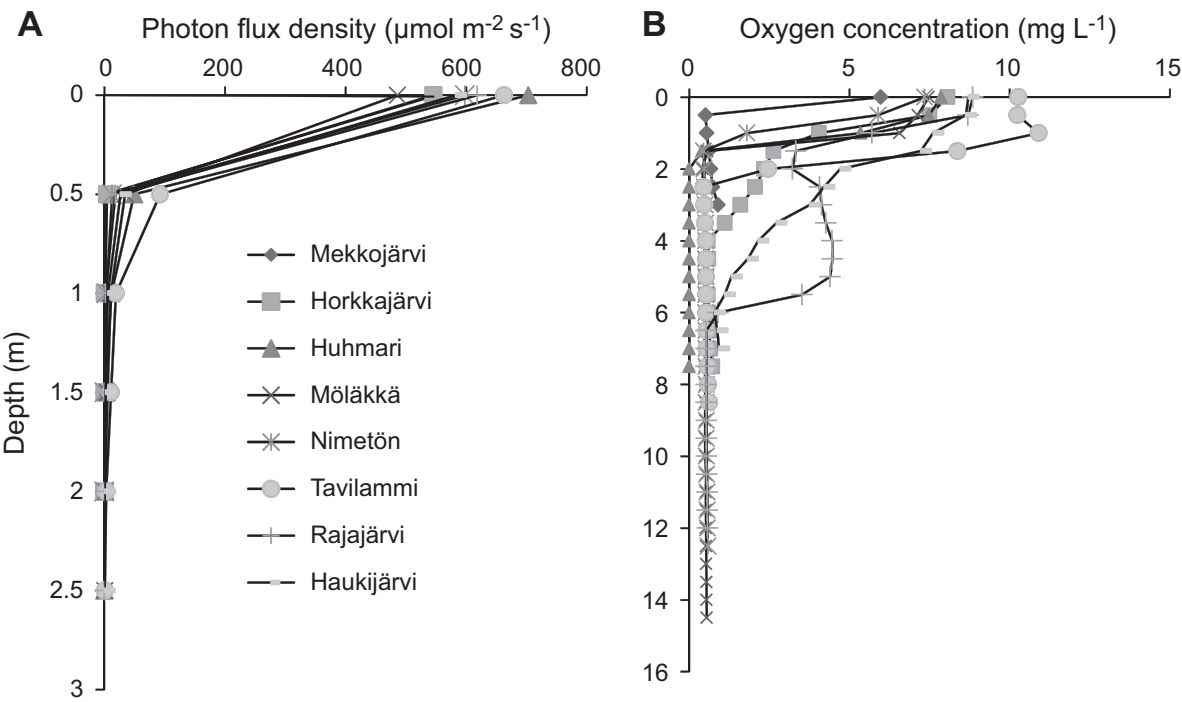

FIG. 1. (A) Light attenuation in the study lakes in July 2015 when incident light at the lake surface was set to $772 \mu \mathrm{mol} \mathrm{m}^{-2}$ $\mathrm{s}^{-1}$. (B) Oxygen concentrations in the study lakes in July 2015.

areas were similar in all eight lakes during the study period (mean $18.0 \pm 0.3^{\circ} \mathrm{C}$ ) and temperature gradients were steep in all the lakes (mean temperature at $2 \mathrm{~m}$ depth $9.0 \pm 0.9^{\circ} \mathrm{C}$ ). Littoral surface temperatures were similar in all the lakes with a mean of $20.6 \pm 0.3^{\circ} \mathrm{C}$ ), and on average 2.5 degrees higher than in the pelagic.

Oxygen concentration gradients were also similarly steep in all the lakes (Fig. 1B). However, Tavilammi, Keskinen Rajajärvi and Haukijärvi had the highest $\mathrm{O}_{2}$ saturation in the surface water (over $90 \%$ ) at noon, and Tavilammi was the only lake in which daytime $\mathrm{O}_{2}$ supersaturation was recorded in the pelagic (Fig. 2A). In contrast, clear $\mathrm{O}_{2}$ supersaturation at noon was observed in the littoral areas of all the lakes except Horkkajärvi and Haukijärvi. Logger data for $\mathrm{O}_{2}$ saturation in Mekkojärvi during July revealed that the littoral was often strongly supersaturated at noon but $\mathrm{O}_{2}$ decreased to almost zero during night (Fig. 2B). The pelagic logger, which was only ca. $1 \mathrm{~m}$ from the edge of the littoral moss mat, showed a similar diel pattern but with clearly lower maximum and higher minimum values, as the $\mathrm{O}_{2}$ saturation usually remained under $80 \%$ at noon and above $20 \%$ at night.

The calculated P:L ratios for each lake are presented in Table 1. The mean P:L ratio was $7.2 \pm 1.9$. The lowest P:L ratios, and, thus the most extensive potential aquatic vegetation cover, were found from Nimetön and Mekkojärvi, and the highest P:L ratio and the least extensive potential vegetation cover from Horkkajärvi.

\section{Pelagic primary production, community respiration and chlorophyll a}

Pelagic NPP $\mathrm{m}^{-3}$ was low in all the lakes (Fig. 3A; mean $55.6 \pm 8.5 \mathrm{mg} \mathrm{C} \mathrm{m}^{-3} \mathrm{~d}^{-1}$ ), and there were no statistically significant differences between the lakes
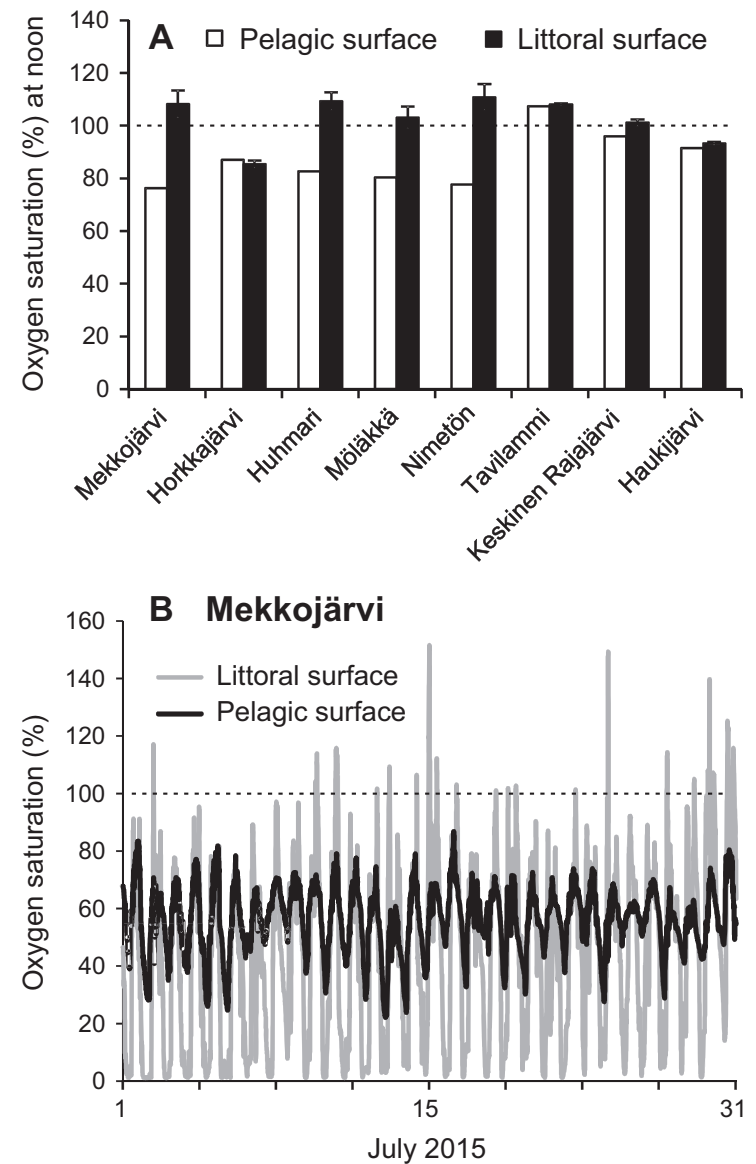

FIG. 2. (A) Oxygen $\%$ saturation in the pelagic and littoral areas (mean $\pm \mathrm{SE}, n=6$ ) in the study lakes at noon in July 2015. (B) Continuously logged data of oxygen \% saturation in the littoral and pelagic areas in Mekkojärvi during July 2015. 

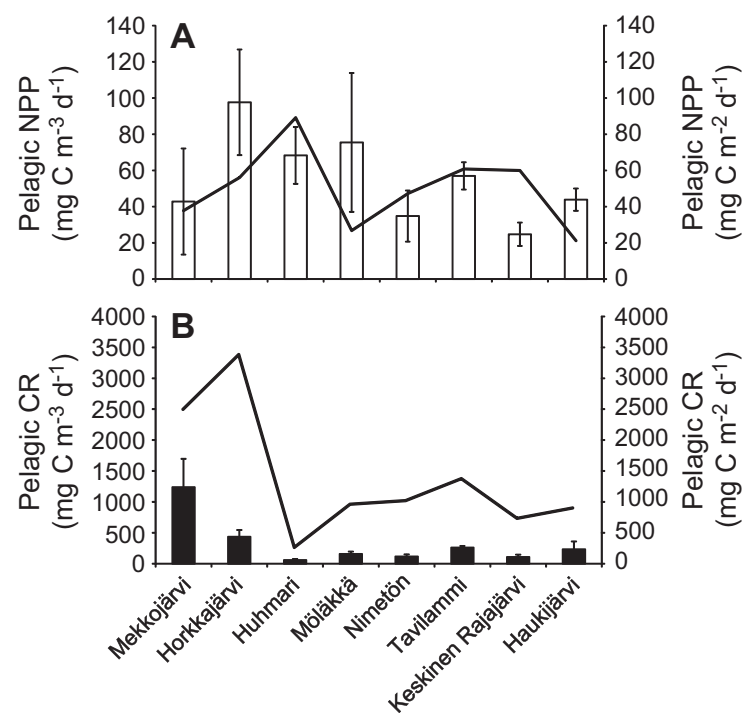

FIG. 3. Pelagic (A) net primary production (NPP) and (B) community respiration $(\mathrm{CR})$ per unit volume (bars, mean $\pm \mathrm{SE}$ ) and per unit area (lines) in the study lakes in July 2015.

(Welch's $t$-test, $t_{7,20.8}=2.2, P=0.079$ ). The mean areal NPP was $50.5 \pm 7.6 \mathrm{mg} \mathrm{C} \mathrm{m}^{-2} \mathrm{~d}^{-1}$.

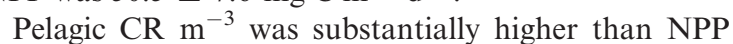
(Fig. 3B; mean $363 \pm 137 \mathrm{mg} \mathrm{C} \mathrm{m}^{-3} \mathrm{~d}^{-1}$ ), and there were statistically significant differences between the lakes (Welch's $t$-test, $t_{7 .,} 22.0=4.4, P<0.01$ ) which, according to the Tukey post hoc test, were between Mekkojärvi and Huhmari, Mekkojärvi and Nimetön and Mekkojärvi and Keskinen-Rajajärvi. The mean areal $\mathrm{CR}$ value was $1375 \pm 364 \mathrm{mg} \mathrm{C} \mathrm{m}^{-2} \mathrm{~d}^{-1}$, and the highest values were in Horkkajärvi and Mekkojärvi (Fig. 3B).

Epilimnetic chl $a$ in the lakes (Table 1) ranged from $1.5 \mathrm{mg} \mathrm{m}^{-3}$ in Nimetön to $15.1 \mathrm{mg} \mathrm{m}^{-3}$ in Keskinen Rajajärvi (mean $6.8 \pm 1.5 \mathrm{mg} \mathrm{m}^{-3}$ ). No significant relationship was observed between epilimnetic NPP and chl $a$ (linear regression, $R^{2}=0.083, F_{1,6}=0.54, P=0.489$ ). However, most of the study lakes contain appreciable quantities of bacteriochlorophyll (BChl), which overlaps with chl $a$ in spectrophotometric determination (Karhunen et al. 2013) and may obscure any potential correlation between the NPP and chl $a$.

\section{Littoral primary production, community respiration and periphyton biomass}

Periphyton NPP in the littoral at noon (Fig. 4A) varied substantially between the lakes (mean $22.9 \pm 4.4 \mathrm{mg} \mathrm{C}$ (g DW substratum $\left.)^{-1} \mathrm{~h}^{-1}\right)$. The highest values were observed in Mekkojärvi and Nimetön and the lowest value in Horkkajärvi. There was a statistically significant difference in noon values between the lakes (Welch's $t$-test, $\left.t_{7,23.2}=9.810, P<0.001\right)$. Tukey's post hoc test revealed that Mekkojärvi differed from Tavilammi, Keskinen Rajajärvi and Haukijärvi, whereas Horkkajärvi differed from all the lakes except Tavilammi, Keskinen Rajajärvi and Haukijärvi. Huhmari and Möläkkä differed only from Horkkajärvi, whereas Nimetön differed from Horkkajärvi, Tavilammi, Keskinen Rajajärvi and Haukijärvi. Tavilammi differed from Nimetön and Mekkojärvi, and both Keskinen-Rajajärvi and Haukijärvi differed from Mekkojärvi and Nimetön, Daily NPP values (g DW substratum) $)^{-1}$ (Fig. 4A) were also highest in Nimetön and Mekkojärvi and lowest in Horkkajärvi (mean daily NPP $251 \pm 99 \mathrm{mg} \mathrm{C}$ (g DW substratum $)^{-1} \mathrm{~d}^{-1}$.

There was also substantial variation in periphyton $\mathrm{CR}$ between the lakes (Fig. 4A; mean \pm SE noon value $14.5 \pm 2.1 \mathrm{mg} \mathrm{C}(\mathrm{g} \text { DW substratum })^{-1} \mathrm{~h}^{-1}$ ) with the highest values in Möläkkä, Mekkojärvi and Nimetön. There were statistically significant differences between the lakes (Welch's $t$-test, $t_{7,33.2}=8.862, P<0.001$ ). Tukey's post hoc test revealed that Mekkojärvi differed from Horkkajärvi, Tavilammi and Keskinen Rajajärvi and
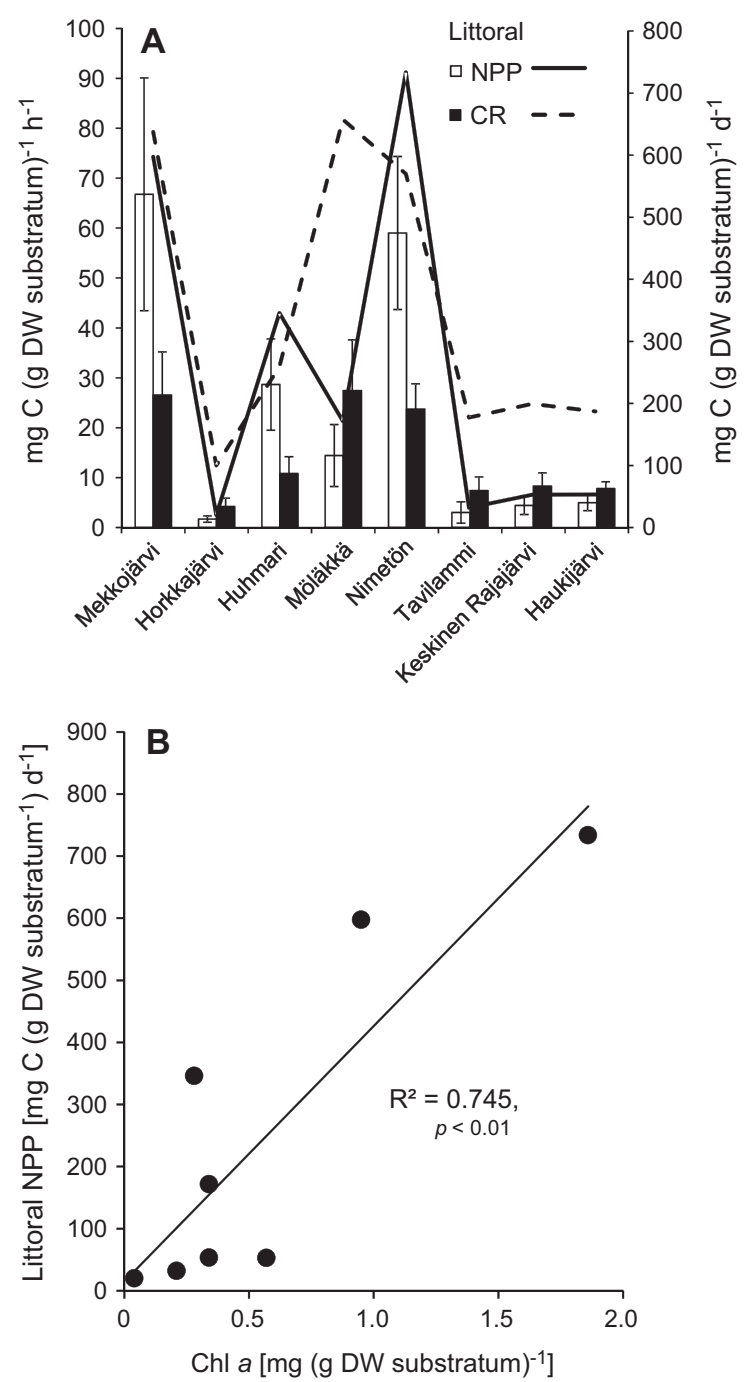

FIG. 4. (A) Mean ( \pm SE) littoral net primary production (NPP) and community respiration (CR) per hour (boxes) and per day (lines) in the study lakes. (B) The relationship between littoral NPP and and chlorophyll $a$. 
Horkkajärvi differed from Mekkojärvi, Möläkkä and Nimetön. Möläkkä differed from Horkkajärvi and Tavilammi, whereas Nimetön differed from Horkkajärvi, Tavilammi and Keskinen Rajajärvi. Tavilammi differed from Mekkojärvi, Möläkkä and Nimetön, whereas Keskinen-Rajajärvi differed from Mekkojärvi and Nimetön.

Periphyton chl $a$ varied substantially between the lakes (mean $0.55 \pm 0.11 \mathrm{mg}(\mathrm{g} \mathrm{DW} \text { substratum })^{-1}$ ), and there were statistically significant differences between lakes (Welch's $t$-test, $t_{7,15.5}=15.525, P<0.001$ ). The highest chl $a$ content was recorded from Nimetön $(1.8 \pm 0.6 \mathrm{mg}$ $(\mathrm{g} \mathrm{DW} \text { substratum })^{-1}$ ) and the lowest from Horkkajärvi

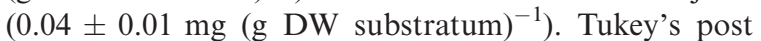
hoc test revealed that Mekkojärvi differed from Horkkajärvi, Horkkäjärvi from Mekkojärvi and Nimetön, and Nimetön differed from Horkkajärvi and Tavilammi. There was a significant positive correlation between the periphyton NPP and chl $a$ (Fig. 4B; linear regression, $\left.R^{2}=0.7451, F_{1,7}=17.7, P<0.01\right)$.

\section{Whole-lake primary production, respiration and production:respiration (GPP:CR) ratios}

Whole-lake extrapolation revealed that the littoral NPP exceeded pelagic PP in five of the eight lakes (Fig. 5A).
Nimetön and Mekkojärvi had over $90 \%$ and Möläkkä over $80 \%$ littoral contribution to whole-lake NPP, while in Horkkajärvi and Tavilammi pelagic was also clearly dominating with over $80 \%$ contribution (Fig. 5B). On average, the littoral contributed $58 \%$ to whole-lake NPP in the study lakes. The pelagic clearly dominated the whole-lake CR in every lake, except in Möläkkä where the littoral contribution of $45 \%$ almost equaled that of the pelagic (Fig. 5C, D). On average, the pelagic contributed $79 \%$ to whole-lake CR in the study lakes.

GPP:CR ratios demonstrate predominant net heterotrophy in the pelagic areas and net autotrophy in the littoral areas (Fig. 6). The mean GPP:CR ratio in the study lakes was $0.09 \pm 0.05$ in the pelagic and $1.59 \pm 0.17$ in the littoral. Huhmari had the least heterotrophic pelagic area with a GPP:CR ratio of 0.52 . The highest littoral GPP:CR ratios were in Huhmari (2.33), Nimetön (2.28) and Mekkojärvi (1.93). When pelagic and littoral were combined, the mean whole-lake GPP:CR ratio was $0.22 \pm 0.09$. Huhmari, with a GPP: CR ratio of 0.78 , had the least heterotrophic lake; Horkkajärvi and Tavilammi, with GPP:CR of 0.02 and 0.05 , were the most heterotrophic.

A significant negative relationship between whole-lake littoral NPP and P:L ratio was observed (Fig. 7A; inverse
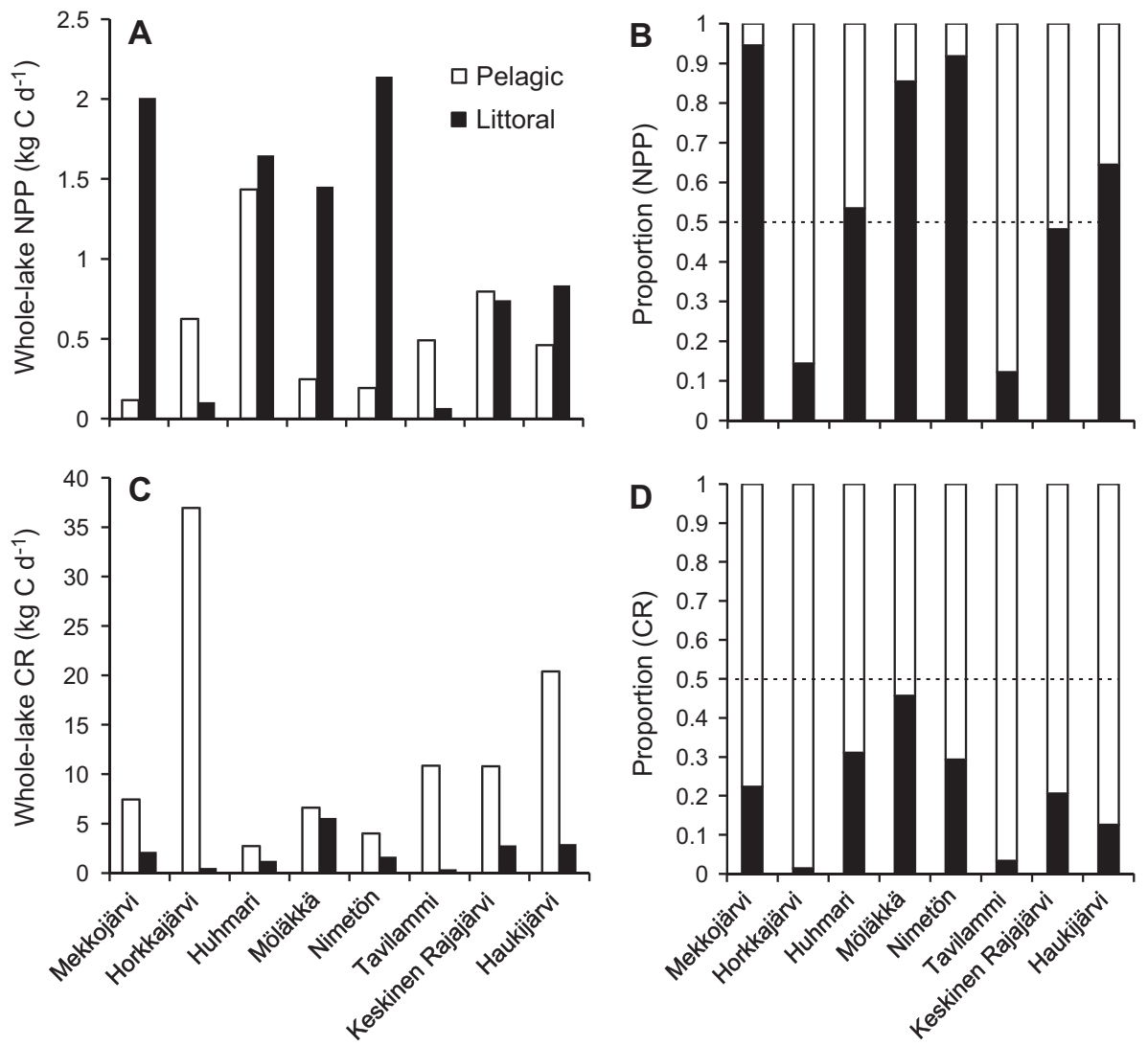

FIG. 5. (A) Whole-lake net primary production (NPP) in the pelagic and littoral areas in the study lakes and, (B) their proportions of the whole-lake PP. (C) Whole-lake community respiration (CR) in the pelagic and littoral areas in the study lakes and, (D) their proportions of the whole-lake CR. 


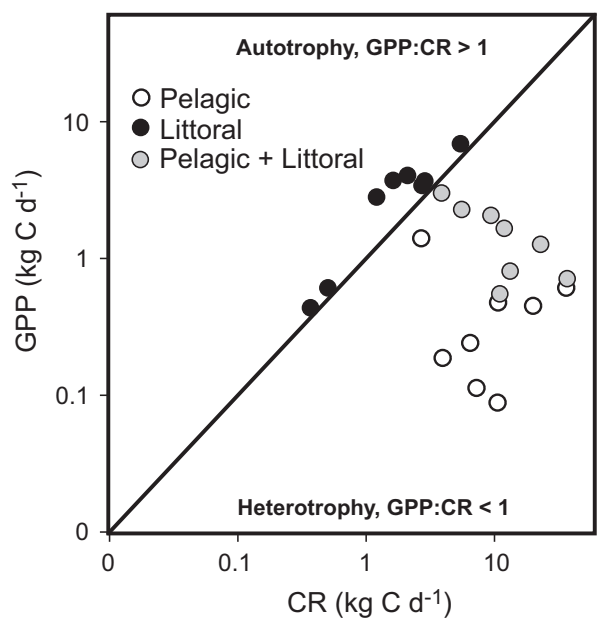

FIG. 6. The relationship between gross primary production (GPP) and community respiration (CR) in the pelagic, littoral and whole lake (both habitats combined) in the study lakes. Since autotrophic respiration was not measured in this study, the ${ }^{14} \mathrm{C}$-values of PP for the pelagic were here taken as GPP. The line represents a GPP:CR ratio of 1 (i.e. metabolic balance) linear regression, $R^{2}=0.700, F_{1,6}=14.01, P=0.01$, and logarithmic regression, $R^{2}=0.686, \quad F_{1},{ }_{6}=13.10$, $P=0.011)$, demonstrating higher littoral NPP with increasing relative potential vegetation cover. A strong negative logarithmic relationship was also observed between the littoral proportion of whole-lake NPP and P: $\mathrm{L}$ ratio (Fig. 7B; logarithmic regression, $R^{2}=0.754, F_{1}$, ${ }_{6}=18.416 . P<0.01$ ), which demonstrates higher littoral contribution to whole-lake PP with increasing relative potential vegetation cover. This was also supported by the strong positive linear relationship between the littoral proportion of whole-lake NPP and the fraction of littoral vegetation cover of the lake surface area (Fig. $7 \mathrm{C}$; linear regression, $\left.R^{2}=0.744, F_{1,6}=17.395 . P<0.01\right)$. There was a strong and statistically significant logarithmic relationship between the littoral $\mathrm{O}_{2}$ saturation and littoral NPP [mg C (g DW substratum $)^{-1} \mathrm{~h}^{-1}$ ] for data from seven of the lakes with Tavilammi excluded (Fig. 7D solid line; linear regression, $R^{2}=0.853, \quad F_{1,}=28.918$, $P<0.01$ ); with Tavilammi included the relationship was weaker but significant (Fig. 7D dashed line; logarithmic regression, $R^{2}=0.540, F_{1,6}=7.046, P<0.05$ ). Periphyton NPP was very low in Tavilammi but the littoral
A

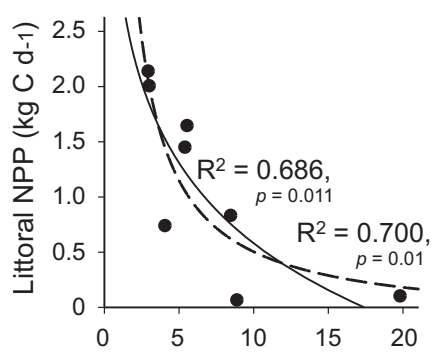

B

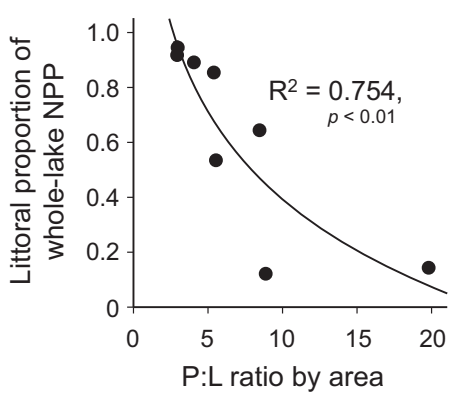

C

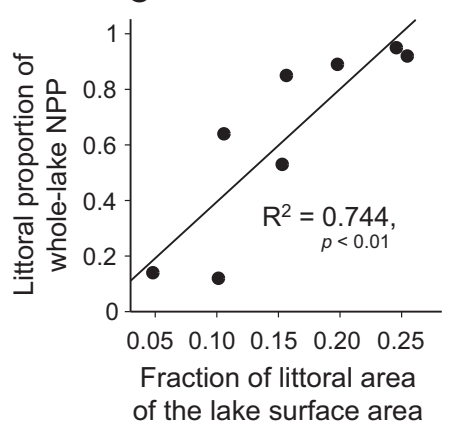

D

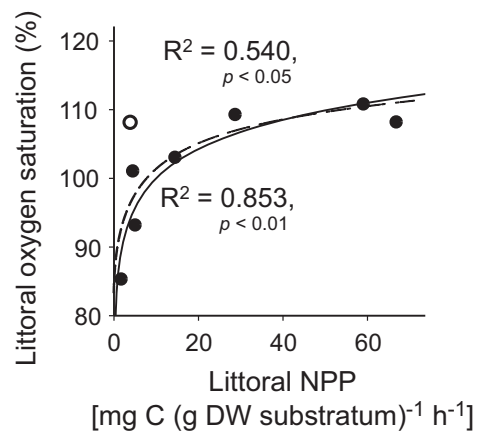

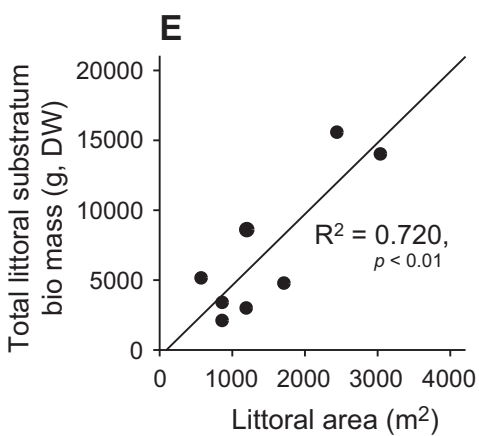

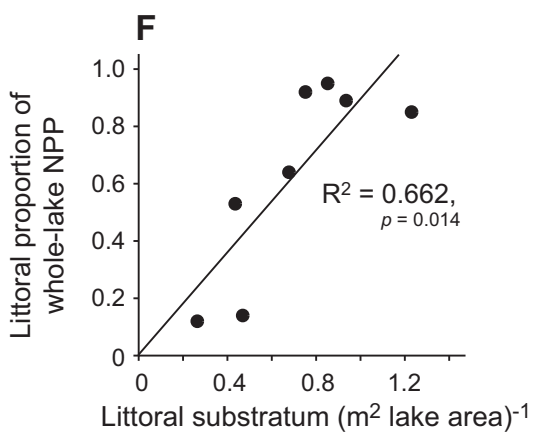

$(\mathrm{g}, \mathrm{DW})$

FIG. 7. (A) Inverse linear (dashed line) and logarithmic (solid line) relationships between whole-lake littoral NPP and pelagic: littoral ratio by area (P:L ratio). (B) Logarithmic relationship between littoral proportion of whole-lake NPP and P:R ratio by area. (C) Linear relationship between littoral proportion of whole-lake NPP and the fraction of the lake surface area occupied by littoral vegetation. (D) Logarithmic relationship between littoral daytime oxygen saturation and littoral NPP at noon, where the solid line has been fitted to data from only 7 lakes (omitting Lake Tavilammi shown by the open circle). (E) Linear relationship between the total dry-weight littoral substratum biomass and the littoral area. (F) Linear relationship between the littoral proportion of wholelake NPP and the littoral substratum dry-weight per square meter of lake area. 
surface water was supersaturated with $\mathrm{O}_{2}$ as was the pelagic, presumably due to relatively high phytoplankton production in both habitats. A positive linear regression was found between the total littoral substratum biomass and total littoral area (extent of macrophyte cover) (Fig. 7E; linear regression, $R^{2}=0.720, F_{1,6}=15.328, P<0.01$. Furthermore, a positive linear regression was found between the littoral proportion of whole-lake NPP and littoral substratum per $\mathrm{m}^{2}$ of lake area (dry-weight, g) (Fig. 7F; linear regression, $R^{2}=0.662, F_{1,6}=11.750$, $P=0.014$. There was no significant relationship between the littoral proportion of whole-lake NPP and DOC concentration (linear regression, $R^{2}=0.064, F_{1,5}=0.343$, $P=0.584)$.

\section{Discussion}

Our study addressed the often neglected but important question of the relative contributions of pelagic phytoplankton and littoral periphyton to whole-lake PP in lake ecosystems (Cantonati and Lowe 2014), focusing on small and highly humic boreal lakes. Our results test the generality of the recent demonstration of littoral periphyton dominance of whole-lake PP in Mekkojärvi (Vesterinen et al. 2016) by surveying whole-lake PP in eight small humic lakes in southern Finland. Our demonstration of littoral dominance of whole-lake PP in five of the eight lakes in July 2015 suggests that this is probably a widespread characteristic of such lakes. The recorded $\mathrm{O}_{2}$ supersaturation in the littoral areas in most of the lakes during the study provides an additional indication of high littoral PP, which also correlated positively with periphyton NPP in the littoral. The significant negative relationship between littoral NPP and P:L ratio by area demonstrates how an increase in littoral vegetation cover and the resulting increase in substrata available for colonization by periphyton can increase littoral NPP and its contribution to whole-lake PP in highly humic lakes. Accounting for littoral PP by periphyton can alter the perceived whole-lake metabolism of these lakes, which have previously been considered strongly net heterotrophic according to pelagic measurements alone, by shifting them towards autotrophy. Furthermore, as macrophytes themselves may appreciably increase $\mathrm{CO}_{2}$ uptake (Brothers et al. 2013, Peixoto et al. 2016), their carbon fixation together with that of associated periphyton may even shift these small humic lakes to net autotrophic in summer. Thus increased DOC concentration, which has been reported to increase net heterotrophy in lakes through the respiration of allochthonous $\mathrm{C}$ and through the decrease in both pelagic and benthic PP due to restricted light penetration (Ask et al. 2012, Godwin et al. 2014), is not always a good single predictor of whole-lake production and metabolism. Littoral vegetation cover and the associated periphyton need to be taken into account, since the periphyton can form highly productive biofilms under shallow well-lit conditions even in highly humic lakes. We did not find any significant relationship between DOC concentration and the proportion of littoral of the whole-lake NPP, likely because the epiphytic algae principally colonized barely submerged and dense (self-shading) plant substrata, when the amount of substrata was a more important factor than DOC (and further, light attenuation). However, our study encompassed only eight rather similar small humic lakes and measured only epiphytic PP in the littoral. Data from a greater range of lakes across a DOC gradient and including many types of littoral development and also measurements of benthic algal production will be needed to make reliable and generalizable conclusions about relationships between DOC, epiphytic PP and littoral contribution to whole-lake PP in humic lakes.

As the area of our study lakes and their P:L ratios by area are both small, the littoral in these lakes is a relatively large proportion of the lake surface area and contributes strongly to whole-lake metabolism. When P:L ratio by area increases together with lake depth, the overall net heterotrophy increases and the relative importance of the littoral in whole-lake metabolism decreases. In this study we defined the littoral area as the area of vegetation cover, and greater vegetation cover was associated with higher littoral NPP by epiphyton. Low development of both periphyton and littoral vegetation was evident in the lakes that had most shading by trees. As a few of the study lakes have some illuminated sediments/rocks, and, thus likely also some associated benthic algae, our definition of the littoral is incomplete. Therefore, our estimates of whole-lake littoral PP are likely underestimates, at least for some of the lakes. However, any contribution to whole-lake PP from benthic algae other than those associated with the shallow littoral vegetation is probably very small due to the low light penetration into the water in every lake. Although the eight lakes in this study remained net heterotrophic when the whole-lake GPP:CR ratios were calculated, incorporation of the net autotrophic littoral into the calculation shifted them towards metabolic balance. As our study only encompassed PP and CR on a single summer day in each lake, it does not account for temporal variation of the PP and CR rates, which was demonstrated in Mekkojärvi in 2012 by Vesterinen et al. (2016). However, the logger data from Mekkojärvi during July shows pronounced weather-associated temporal variation in $\mathrm{O}_{2}$ saturation, which indicates high variation in PP rates and metabolism during summer. Comparison of pelagic and littoral loggers also indicates substantial spatial heterogeneity in PP rates in the lake, as shown by Van de Bogert et al. (2007). The remarkable differences in $\mathrm{O}_{2}$ saturation between the pelagic and littoral loggers only ca $1 \mathrm{~m}$ apart, demonstrate very low horizontal fluxes between the pelagic and littoral in the small and sheltered Mekkojärvi.

Comparison of metabolism of different lakes can be misleading when lakes are not sampled simultaneously and the weather changes during the sampling period. The days when Mekkojärvi and Horkkajärvi were sampled in this study were cloudier than the rest of the 
sampling days, which were all sunny and almost cloudless. This particularly affects the relationship between PP and CR by reducing PP. For instance, Mekkojärvi was found to be frequently net autotrophic during summer 2012 (Vesterinen et al. 2016), but was net heterotrophic in this study. This could be a result of lower light and reduced PP together with higher respiration in the lake. Indeed, pelagic CR was particularly high in Mekkojärvi relative to its smaller lake volume than in the other study lakes. This illustrates the temporal variation in metabolism which occurs both within and between years. However, a considerable difference between this and the 2012 study (Vesterinen et al. 2016) was in estimation of pelagic GPP. Autotrophic respiration was not measured directly in either study. In 2012, pelagic GPP was estimated as the sum of ${ }^{14} \mathrm{C} P P$ values and $\mathrm{CR}$ over the photic zone. Since this can seriously overestimate the pelagic GPP, we were conservative and used the ${ }^{14} \mathrm{C}$ values in this study. However, there is also debate about whether the ${ }^{14} \mathrm{C}$ incorporation technique most closely estimates NPP or GPP (Marra 2009). The technique has been widely used in studies of humic lakes, with an incubation time of $24 \mathrm{~h}$ considered to approximate NPP, so our pelagic and whole-lake GPP:CR ratios based on the technique are likely underestimates.

The upscaling of rate estimates made in bottle incubations to the ecosystem level inevitably has marked uncertainties (Hanson et al. 2015). Considering this, our whole-lake littoral PP and CR estimates from the structurally more complex littoral zones undoubtedly involve higher uncertainty than those from the more homogenous pelagic. However, as the rates were so high, the associated uncertainty cannot alter the essential message of highly important littoral autotrophic production in most of the lakes. Moreover, as the littoral NPP values were calculated by subtracting CR from GPP and the true autotrophic respiration must be less than the measured total CR, the littoral NPP values must actually be underestimates. The P:L ratios by area were obtained using areal calculations from satellite imagery, which undoubtedly gives only coarse estimates due to rather low resolution. However, P:L ratios correlated significantly with the littoral NPP estimates, demonstrating the validity of our approach, which nevertheless might be improved with higher resolution satellite imagery.

The relative contribution of littoral and pelagic habitats to whole-lake PP is a fundamental ecosystem attribute that remains poorly explored and is in urgent need of further study (Vadeboncoeur et al. 2002, Cantonati and Lowe 2014). Our study addressed this using a novel approach to demonstrate the importance of littoral PP in humic lakes. However, all of our study lakes are small and shallow, and most of them have relatively large fractions of the lake surface area covered by littoral vegetation; therefore whether the reported relationship between littoral epiphytic NPP and P:L ratio (defined as the extent of littoral vegetation cover) is also applicable to larger humic lakes remains to be tested. Depth ratio
$\left(\mathrm{DR}=\bar{z} / z_{\max }\right)$ together with light attenuation have been used for predicting benthic algal contribution to wholelake PP, which in deeper oligotrophic and mesotrophic lakes is predicted as moderate, ranging between 10 and $50 \%$ (Vadeboncoeur et al. 2008). DR alone tells us little about the distribution of illuminated benthic habitat. If the mean depth is well below the depth $1 \%$ of light, the majority of benthic habitat is not illuminated, and the benthic algae contributes only little to whole-lake PP regardless of DR (Vadeboncoeur et al. 2008). Whether the P:L ratio by area increases along with increasing lake size depends on light availability and lake morphometry. Allochthonous DOM is a major factor controlling light availability in oligotrophic lakes (Ask et al. 2009b), and DOC concentration is very strongly connected to the light penetration into water particularly in small boreal lakes (Jones and Arvola 1984). Larger lakes tend to be less humic than the small ones due to relatively much smaller allochthonous DOM loads and faster net sedimentation rate of humic matter (Eloranta 1999). Thus, the increase in lake size increases available habitats for benthic algae and the total area of littoral zone. Lake morphometry also affects the distribution of macrophytes in lakes. Shallow humic lakes with clearly larger surface area than our study lakes can have very high macrophyte cover providing extensive substrata for epiphyton under well-lit conditions, as has been demonstrated in some humic lakes in South American wetlands (Rodríguez et al. 2012). Lakes with similar characteristics can be found also in the boreal zone, although P:L ratios presumably tend to increase in larger humic boreal lakes. However, the extent of macrophyte cover together with illuminated sediments should be quantified in order to estimate the P:L ratios and whole-lake PP also in larger humic lakes. The model fit to our data suggests $<10 \%$ littoral contribution to whole-lake PP in lakes with P:L ratio over 20, but empirical studies are needed to test this for higher number of lakes including larger ones. Improved satellite imagery can be an effective tool for such studies, which are technically challenging, yet necessary. Since our study relates to a short period during mid-summer, the temporal factor should be accounted for together with a larger data set to better understand the relations between the littoral and pelagic production and their contributions to lake metabolism over the annual cycle. The period of high littoral production is short whereas respiration potentially takes place all year round.

As littoral zones are very abundant and are among the most productive ecosystems in the world (Wetzel 1990), greater focus on their trophic structure, metabolism and biogeochemistry is very important. The number of boreal lakes similar to those we studied is very high globally (Downing et al. 2006). Thus, their role in regional C budgets is large and they are considered "hotspots" of C sequestration, receiving high allochthonous inputs, which shift these systems towards heterotophy (Cole 2013). The data presented here suggest that many of these lakes are actually more productive and not as heterotrophic as is 
previously assumed, when the potentially high production of periphyton on aquatic vegetation is incorporated into whole primary production models.

\section{ACKNOWLEDGMENTS}

We thank Lammi Biological Station for both financial support to JV and for accommodation and laboratory facilities. Thanks to Lauri Arvola for sharing data from the study lakes and loaning the data loggers. We also acknowledge financial support to JV from the Maj and Tor Nessling Foundation and the Doctoral Programme in Biological and Environmental Science of the University of Jyväskylä, and support from the Academy of Finland (projects 137671 to RJ and 296918 to JS) and from the Marie Skłodowska-Curie Actions (660655 to JS) under the EU Horizon 2020 Programme.

\section{Literature Cited}

Andersson, E., and A. Brunberg. 2006. Net autotrophy in an oligotrophic lake rich in dissolved organic carbon and with high benthic primary production. Aquatic Microbial Ecology 43:1-10.

Arvola, L., M. Rask, J. Ruuhijärvi, T. Tulonen, J. Vuorenmaa, T. Ruoho-Airola, and J. Tulonen. 2010. Long-term patterns in $\mathrm{pH}$ and colour in small acidic boreal lakes of varying hydrological and landscape settings. Biogeochemistry 101: 269-279.

Ask, J., J. Karlsson, L. Persson, P. Ask, P. Byström, and M. Jansson. 2009a. Whole-lake estimates of carbon flux through algae and bacteria in benthic and pelagic habitats of clear-water lakes. Ecology 90:1923-1932.

Ask, J., J. Karlsson, L. Persson, and P. Ask. 2009b. Terrestrial organic matter and light penetration: effects on bacterial and primary production in lakes. Limnology and Oceanography 54:2034-2040.

Ask, J., J. Karlsson, and M. Jansson. 2012. Net ecosystem production in clear-water and brown-water lakes. Global Biogeochemical Cycles 26. GB1017. doi:10.1029/2010GB003951

Brothers, S. M., S. Hilt, S. Meyer, and J. Köhler. 2013. Plant community structure determines primary productivity in shallow, eutrophic lakes. Freshwater Biology 58:2264-2276.

Brothers, S., J. Köhler, K. Attermeyer, H. P. Grossart, T. Mehner, N. Meyer, K. Scharnweber, and S. Hilt. 2014. A feedback loop links brownification and anoxia in a temperate, shallow lake. Limnology and Oceanography 59:1388-1398.

Cantonati, M., and R. L. Lowe. 2014. Lake benthic algae: toward an understanding of their ecology. Freshwater Science $33: 475-486$.

Cole, J. J. 2013. Why is there so much organic carbon in the sediments of lakes? Pages 104-107 in O. Kinne, editor. Freshwater ecosystems and the carbon cycle. International Ecology Institute, Oldendorf/Luhe, Germany.

Del Giorgio, P. A., and R. H. Peters. 1994. Patterns in planktonic $\mathrm{P}: \mathrm{R}$ ratios in lakes: influence of lake trophy and dissolved organic carbon. Limnology and Oceanography 39: 772-787.

Devlin, S. P., M. J. Vander Zanden, and Y. Vadeboncoeur. 2015. Littoral-benthic primary production estimates: sensitivity to simplifications with respect to periphyton productivity and basin morphometry. Limnology and Oceanography: Methods $14: 138-149$

Downing, J., et al. 2006. The global abundance and size distribution of lakes, ponds, and impoundments. Limnology and Oceanography 51:2388-2397.

Duarte, C. M., and S. Agusti. 1998. The $\mathrm{CO}_{2}$ balance of unproductive aquatic ecosystems. Science 281:234-236.
Eloranta, P. 1999. Humic matter and water colour. Page 61-74 in J. Keskitalo, and P. Eloranta, editors. Limnology of humic waters. Backhuys Publishers, Leiden, The Netherlands.

Godwin, S. C., S. E. Jones, B. C. Weidel, and C. T. Solomon. 2014. Dissolved organic carbon concentration controls benthic primary production: results from in situ chambers in northtemperate lakes. Limnology and Oceanography 59:2112-2120.

Hanson, P. C., M. L. Pace, S. R. Carpenter, J. J. Cole, and E. H. Stanley. 2015. Integrating landscape carbon cycling: research needs for resolving organic carbon budgets of lakes. Ecosystems 18:363-375.

Hill, W. R. 1996. Effect of light. Pages 121-148 in R. J. Stevenson, M. L. Bothwell, and R. L. Lowe, editors. Algal ecology: freshwater benthic ecosystems. Academic Press, San Diego, USA.

Järvinen, M., M. Rask, J. Ruuhijärvi, and L. Arvola. 2002. Temporal coherence in water temperature and chemistry under the ice of boreal lakes (Finland). Water Research 36:3949-3956.

Jeppesen, E., M. Sondergaard, M. Sondergaard, and K. Christofferson. 2012. The structuring role of submerged macrophytes in lakes. Springer Science \& Business Media, New York, USA.

Jones, R. I., and L. Arvola. 1984. Light penetration and some related characteristics in small forest lakes in Southern Finland. Verhandlungen des Internationalen Verein Limnologie 22:811-816.

Karhunen, J., L. Arvola, S. Peura, and M. Tiirola. 2013. Green sulphur bacteria as a component of the photosynthetic plankton community in small dimictic humic lakes with an anoxic hypolimnion. Aquatic Microbial Ecology 68:267-272.

Karlsson, J., P. Byström, J. Ask, P. Ask, L. Persson, and M. Jansson. 2009. Light limitation of nutrient-poor lake ecosystems. Nature 460:506-509.

Kortelainen, P. 1999. Organic carbon concentrations in boreal lakes. Pages 50-57 in J. Keskitalo, and P. Eloranta, editors. Limnology of humic waters. Backhuys Publishers, Leiden, The Netherlands.

Marra, J. 2009. Net and gross productivity: weighing in with ${ }^{14}$ C. Aquatic Microbial Ecology 56:123-131.

Messager, M. L., B. Lehner, G. Grill, I. Nevada, and O. Schmitt. 2016. Estimating the volume and age of water stored in global lakes using a geostatistical approach. Nature Communications 7:13603.

Monteith, D. T., J. L. Stoddard, C. D. Evans, H. A. de Wit, M. Forsius, T. Høgåsen, A. Wilander, B. L. Skjelkvåle, D. S. Jeffries, and J. Vuorenmaa. 2007. Dissolved organic carbon trends resulting from changes in atmospheric deposition chemistry. Nature 450:537-540.

Peixoto, R., H. Marotta, D. Bastviken, and A. Enrich-Prast. 2016. Floating aquatic macrophytes can substantially offset open water $\mathrm{CO}_{2}$ emissions from tropical floodplain lake ecosystems. Ecosystems 19:724-736.

R Core Team. 2016. R: A language and environment for statistical computing. R Foundation for Statistical Computing, Vienna, Austria. https://www.R-project.org/.

Rintanen, T. 1996. Changes in the flora and vegetation of 113 Finnish lakes during 40 years. Annales Botanici Fennici 33:101-122

Rodríguez, P., M. S. Vera, and H. Pizarro. 2012. Primary production of phytoplankton and periphyton in two humic lakes of a South American wetland. Limnology 13:281-287.

Salonen, K. 1981. Rapid and precise determination of total inorganic carbon and some gases in aqueous solutions. Water Research 15:403-406.

Salonen, K., and A. Holopainen. 1979. A comparison of methods for the estimation of phytoplankton primary production. Internationale Revue der Gesamten Hydrobiologie und Hydrographie 64:147-155. 
Schindler, D. W., R. V. Schmidt, and R. A. Reid. 1972. Acidification and bubbling as an alternative to filtration in determining phytoplankton production by the ${ }^{14} \mathrm{C}$ method. Journal of the Fisheries Research Board of Canada 29:1627-1631.

Shorthouse, D. P. 2010. SimpleMappr, an online tool to produce publication-quality point maps. [Retrieved from http://www. simplemappr.net. Accessed October 11, 2016].

Solomon, C. T., S. E. Jones, B. C. Weidel, I. Buffam, M. L. Fork, J. Karlsson, S. Larsen, J. T. Lennon, J. S. Read, and S. Sadro. 2015. Ecosystem consequences of changing inputs of terrestrial dissolved organic matter to lakes: current knowledge and future challenges. Ecosystems 18:376-389.

Vadeboncoeur, Y., M. J. Vander Zanden, and D. M. Lodge. 2002. Putting the Lake Back Together: Reintegrating Benthic Pathways into Lake Food Web Models Lake ecologists tend to focus their research on pelagic energy pathways, but, from algae to fish, benthic organisms form an integral part of lake food webs. BioScience 52:44-54.

Vadeboncoeur, Y., E. Jeppesen, M. Zanden, H. Schierup, K. Christoffersen, and D. M. Lodge. 2003. From Greenland to green lakes: cultural eutrophication and the loss of benthic pathways in lakes. Limnology and Oceanography 48: 1408-1418.
Vadeboncoeur, Y., G. Peterson, M. J. Vander Zanden, and J. Kalff. 2008. Benthic algal production across lake size gradients: interactions among morphometry, nutrients, and light. Ecology 89:2542-2552.

Van de Bogert, M. C., S. R. Carpenter, J. J. Cole, and M. L. Pace. 2007. Assessing pelagic and benthic metabolism using free water measurements. Limnology and Oceanography $5: 145-155$

Vehkaoja, M., P. Nummi, M. Rask, T. Tulonen, and L. Arvola. 2015. Spatiotemporal dynamics of boreal landscapes with ecosystem engineers: beavers influence the biogeochemistry of small lakes. Biogeochemistry 124:405-415.

Vesterinen, J., S. P. Devlin, J. Syväranta, and R. I. Jones. 2016. Accounting for littoral primary production by periphyton shifts a highly humic boreal lake towards net autotrophy. Freshwater Biology 61:265-276.

Vesterinen, J., S. P. Devlin, J. Syväranta, and R. I. Jones. 2017. Epiphytic bacteria make an important contribution to heterotrophic bacterial production in a humic boreal lake. Aquatic Microbial Ecology 79:247-257.

Wetzel, R. G. 1990. Land-water interfaces: metabolic and limnological regulators. Verhandlungen des Internationalen Verein Limnologie 24:6-24.

\section{SUPPORTING INFORMATION}

Additional supporting information may be found in the online version of this article at http://onlinelibrary.wiley.com/doi/ 10.1002/ecy.2012/suppinfo 